\title{
Asosiasi Keragaman Growth Hormone Secretagogue Receptor \\ (GHSR | Hin6i) terhadap Bobot Karkas Ayam Kampung pada Umur 12 Minggu
}

\author{
Polymorphism of GHRELIN RESEPTOR (GHSR | Hin6I) Gene Associated With Carcass Weight on 12 Weeks \\ Age of Kampung Chicken \\ G. Syaikhullah ${ }^{1)}$ S. Darwati ${ }^{2)}$ C. Sumantri ${ }^{2)}$ \\ ${ }^{1)}$ Fakultas Peternakan, Sekolah Pascasarjana, Institut Pertanian Bogor. \\ ${ }^{2}$ Departemen Ilmu Produksi dan Teknologi Peternakan,Fakultas Peternakan, Institut Pertanian Bogor, Jl. \\ Agatis, Kampus IPB Dramaga, Bogor 16680, Indonesia \\ Dramaga, Bogor 16680, Indonesia Correspondence author: 08113002233 / gayuh_syaikhullah@outlook.com
}

\begin{abstract}
ABSTRAK
This study aimed to identify the GHSR genes polymorphism in chickens and to analyze the association of these genes on carcass weight and commercial cuts in chicken. A total of 60 local chickens (33 hen and 27 roosters) was used in this study. The chickens were bred in the colony cages and given full time access (ad libitum) to the commercial feed. The PCR-RFLP method was used to analyzed the gene polymorphism. The Hin6I was used as a restriction enzyme. The genotype frequency, allele frequency and Hardy Weinberg equilibrium were analyzed in this study. The phenotypic characteristics (body weight, carcass weight, breast weight, thigh weight, drumstick weight, wing weight and back weight) were analyzed using $T$ test. The result showed that there were two genotypes (CT and TT) found in kampung chickens. The frequency of CT and TT genotype were 0.317 and 0.683 , respectively. The value of $\mathrm{Ho}$ and He were 0.317 and 0.267 respectively. This population was not equal according to Hardy Weinberg equilibrium analysis. The GHSR gene polymorphism was significantly associated $(\mathbf{P}<\mathbf{0 . 0 5})$ with body weight, carcass weight, breast weight, thigh weight, drumstick weight, wing weight and back weight. The TT genotype was higher than CT genotype on all traits. The locus of GHSR|Hin6I could be used as a marker associated selection (MAS).
\end{abstract}

Keywords: commercial cuts, GHSR gene, kampung chicken, RFLP.

\section{PENDAHULUAN}

Indonesia memiliki ayam lokal yang berpotensi tinggi untuk dikembangkan tingkat produktivitasnya. Terdapat berbagai jenis ayam lokal, baik yang asli maupun hasil adaptasi yang dilakukan puluhan bahkan ratusan tahun yang lalu di Indonesia, dilaporkan terdapat 32 jenis ayam lokal (ecotype) dan masing-masing jenis memiliki keunggulan tersendiri, seperti ayam pelung, sentul, kedu, merawang, gaok, dan nusa penida. Ayam lokal merupakan aset yang sangat berharga dalam pembentukan bibit unggul ayam lokal yang terbukti mampu beradaptasi pada lingkungan setempat (Nataamijaya 2000). Ayam lokal yang tidak memiliki karakteristik khusus disebut sebagai ayam kampung (Nataamijaya 2010). Ayam kampung merupakan plasma nutfah Indonesia yang mempunyai potensi untuk dikembangkan karena memiliki daya adaptasi tinggi. Ayam kampung merupakan ayam lokal Indonesia yang banyak dibudidayakan di masyarakat, namun masih memiliki produktivitas yang rendah di bawah potensi genetiknya (Nataamijaya 2010). Muryanto et al. (2002) menyatakan pengembangan ayam kampung memiliki kendala pada lambatnya laju reproduksi dan pertumbuhan.
Sumbangan ayam kampung terhadap produksi daging pada tahun 2015 sebesar 313,9 ribu ton, produksi tersebut menurun dibanding dengan produksi daging pada tahun 2013 sebesar 319,5 ribu ton (Direktorat Jendral Peternakan 2015). Rendahnya produktivitas ayam kampung berbanding terbalik dengan permintaan konsumsi daging ayam kampung di masyarakat. Selain itu, kendala kurang minatnya peternak skala besar untuk beternak ayam kampung dikarenakan ayam kampung memiliki pertumbuhan lambat untuk mencapai bobot potong dibandingkan ayam ras pedaging (Darwati 2001). Oleh karena itu, perlu dilakukan perbaikan mutu genetik ayam kampung untuk meningkatkan efesiensi budidaya ayam kampung. Salah satu metode yang dapat dilakukan adalah dengan seleksi berbasis gen spesifik yang berpangaruh pada sifat pertumbuhan.

Growth Hormone Secretagogue Receptor (GHSR), terlibat dalam banyak fungsi fisiologis, termasuk sekresi hormon pertumbuhan hipofisis, asupan makanan dan pengeluaran energi (Fang et al. 2010). Gen GHSR adalah gen yang berperan penting sebagai resptor utama dalam proses sekresi GH atau yang sering disebut dengan growth hormone (Masayasu 2005). Gen GHSR terdiri dari 2 exon 
dan 1 intron (Niarami et al. 2014). Pada studi lain Gen GHSR terbukti mempengaruhi sifat perlemakan daging pada ayam Xinghua. GHSR juga berkaitan dengan tingkat obesitas pada manusia dan tikus. GHSR berinteraksi dengan GHRL dalam proses bioaktivasi melalui jalur neuroendokrin (Lei et al. 2007). Menurut Nie et al. (2009) Gen GHSR juga terlibat dalam sekresi GH, food intake, dan homeostatis energi. Fang et al. (2010) menemukan keragaman lokus gen GHSR di intron 1 pada ayam White Recessive Rock dan Xinghua yang berasosiasi dengan bobot potong umur 28 dan 90 hari, bobot otot dada dan paha. Keragaman ini diakibatkan karena adanya mutasi basa $\mathrm{T}$ menjadi $\mathrm{C}$.

Penelitian ini dilakukan untuk mengidentifikasi keragaman genotipe gen GHSR pada ayam kampung. Selain itu penelitian ini bertujuan untuk menganalisa asosiasi gen tersebut terhadap bobot karkas pada ayam kampung.

\section{MATERI DAN METODE}

\section{Sampel Ternak}

Sampel yang digunakan pada penelitian ini adalah ayam kampung berjumlah 33 ekor ayam betina dan 27 ekor ayam jantan yang dipelihara pada kandang koloni. Populasi ayam tersebut dikoleksi 60 sampel darah ayam kampung umur 12 minggu. Ayam tersebut berasal dari koleksi Laboratorium Lapang Terpadu Fakultas Peternakan IPB. Ayam tersebut mulanya didapat dari sebuah perusahaan peternakan di Banten. Pakan dan minum diberikan adlibitum.

\section{Analisis Genotipe}

Total genom diperoleh dengan metode phenol chloroform (Sambrook et al. 2001) . Primer yang digunakan untuk mengamplifikasi gen GHSR berdasarkan Fang et al. (2010) yang dimodifikasi adalah primer forward (5'-CCC ACA AAG TTA GCT GCA GAC-3') dan primer reverse (5'-CAC CTC TCC ATC TGG CTC ATT3'). Primer tersebut mampu mengamplifikasi gen GHSR sepanjang $470 \mathrm{pb}$ di intron 1. Amplifikasi DNA dilakukan pada total volume $15 \mu \mathrm{L}$ yang terdiri dari $1 \mu \mathrm{L}$ DNA, 0,3 $\mu \mathrm{L}$ primer, 7,5 $\mu \mathrm{L}$ master mix, dan $6,2 \mu \mathrm{L}$ air destilasi. PCR dilakukan pada suhu denaturasi awal pada $94{ }^{\circ} \mathrm{C}$ selama 4 menit yang dilakukan 1 siklus. denaturasi pada suhu $94{ }^{\circ} \mathrm{C}$ selama 10 detik, annealing pada suhu $60{ }^{\circ} \mathrm{C}$ selama 20 detik, ekstensi $72{ }^{\circ} \mathrm{C}$ selama 30 detik (35 siklus) dan ekstensi akhir pada suhu $72^{\circ} \mathrm{C}$ selama 7 menit.

Penentuan genotipe gen GHSR menggunakan metode RFLP. Sebanyak $5 \mu \mathrm{L}$ produk PCR gen GHSR dipotong menggunakan $2 \mu \mathrm{L}$ restriction endonuclease mix yang terdiri dari $1 \mu \mathrm{L} \mathrm{dH} 2 \mathrm{O}, 0,7 \mu \mathrm{L}$ buffer, dan $0,3 \mu \mathrm{L}$ enzim pemotong, kemudian diinkubasi selama 16 jam pada suhu $37{ }^{\circ} \mathrm{C}$. Enzim pemotong yang digunakan untuk gen GHSR adalah Hin6I yang mengenali situs potong G|CGC. Elektroforesis dilakukan pada gel agarose 2\% dengan buffer 0.5 TBE (Tris Borat EDTA) yang dialiri arus listrik dengan tegangan $100 \mathrm{~V}$ selama 40 menit. Visualisasi hasil elektroforesis dilakukan di bawah UV transiluminator.

\section{Analisis Data}

Data yang dianalisis berupa data bobot hidup, bobot karkas dan potongan komersial (dada, paha atas, paha bawah, sayap dan punggung). Data sekuensing dari gen GHSR dianalisis menggunakan program Bioedit (Hall 1999). Identifikasi SNP dilakukan dengan menggunakan program Molecular Evolutionary Genetics Analysis 7 (MEGA 7) dengan nomor referensi AB095994.1 (Tamura et al. 2011). Nilai frekuensi alel, frekuensi genotype, nilai keseimbangan Hardy-Weinberg, heterosigositas pengamatan, heterosigositas harapan dihitung berdasarkan Allendorf (2013). Asosiasi antara gen GHSR dengan sifat yang diamati pada ayam kampung dianalisis menggunakan uji t.

\section{HASIL DAN PEMBAHASAN}

Amplifikasi gen GHSR pada ayam kampung berhasil dilakukan denaturasi awal pada $94{ }^{\circ} \mathrm{C}$ selama 4 menit sebanyak 1 siklus. denaturasi pada suhu $94{ }^{\circ} \mathrm{C}$ selama 10 detik, annealing pada suhu $60{ }^{\circ} \mathrm{C}$ selama 20 detik, ekstensi $72{ }^{\circ} \mathrm{C}$ selama 30 detik (35 siklus) dan ekstensi akhir pada suhu $72{ }^{\circ} \mathrm{C}$ selama 7 menit. Proses tersebut menghasilkan produk sebesar 470 bp (Gambar 1). Hasil amplifikasi dipotong dengan enzim Hin6I menghasilkan 2 genotip, yakni CT dan TT. Hasil RFLP pada gen GHSR menunjukkan bahwa genotip CT memiliki 3 pita 470 bp, 354 bp, dan 116 bp, sedangkan genotip TT memiliki 1 pita 470 bp (Gambar 2). Pada penelitian Fang et al. (2010) ditemukan gen GHSR pada ayam Xinghua dengan 3 varian genotip, yakni CT, TT dan CC.

Gambar 3 menyajikan hasil sekuensing pada gen GHSR di ayam kampung ditemukan adanya delesi pada posisi primer 134 bp yang menyebabkan hilangnya basa C. Alignment pada gen GHSR pada ayam kampung menunjukan adanya mutasi, yaitu basa $\mathrm{T}$ berubah menjadi C. Hal ini bisa disebut sebagai mutasi transversi, yaitu adanya perubahan basa purin menjadi pirimidin. SNP tranversi berpeluang besar dapat menyebabkan perubahan asam amino yang mengakibatkan mutasi non-sinonimous (Allendorf et al. 2013).

Menurut Fang et al. (2010) mutasi pada gen GHSR yang diamati terjadi pada intron 1. Intron juga berisi sekuen DNA yang mengikat enhancer yang mungkin mempengaruhi proses transkripsi. Intron juga mengandung sekuen RNA regulator yang dapat mempengaruhi proses translasi dan stabilitas mRNA. Pada saat sebuah mutasi terjadi, RNA dapat mengubah produk dari sebuah gen. Mutasi di wilayah ini dapat mempengaruhi fungsi gen. Pada proses translasi, intron terlibat dalam proses regulasi aktivitas produksi protein. Mutasi di wilayah ini memiliki kemungkinan untuk mempengaruhi jumlah produksi protein dan fungsi atau ekspresi gen (Perdew et al. 2006)

Menurut Noor (2010) frekuensi genotipe menandakan rasio dari jumlah suatu genotipe terhadap suatu populasi dengan menghitung perbandingan antara jumlah genotipe tertentu pada setiap populasi sedangkan frekuensi alel adalah rasio suatu alel terhadap jumlah keseluruhan alel pada suatu SNP dalam sebuah populasi.

Tabel 1, menunjukkan bahwa frekuensi genotip TT pada gen GHSR lebih besar dibanding genotip CT yaitu sebesar 0,683, sedangkan pada frekuensi genotip CT sebesar 0,317 (Tabel 1). Pada gen GHSR frekuensi alel T sebesar 0,842 dan frekuensi alel C sebesar 0,518. Single Nucleotide Polymorphism (SNP) dikatakan polimorfik jika memiliki nilai frekuensi alel $\leq 0,99$ pada sebuah populasi 


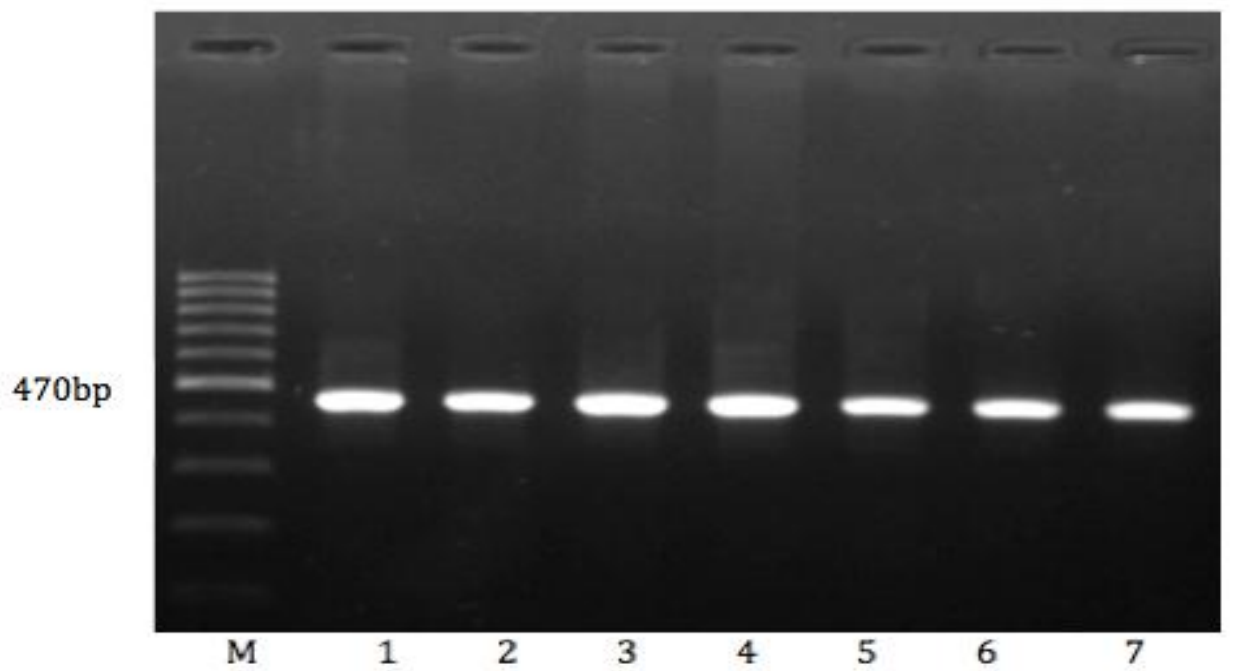

Gambar 1. Hasil amplifikasi gen GHSR pada Intron 1 (M : Marker ; 1-7 : Sampel ayam kampung)

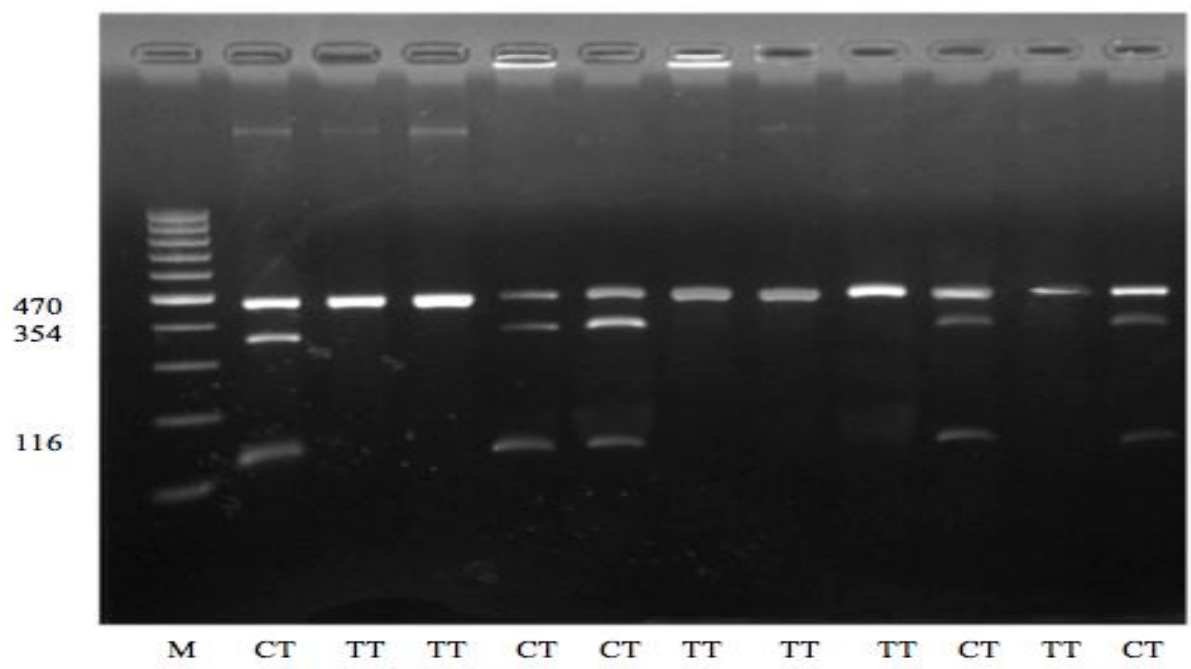

Gambar 2. Hasil RFLP gen GHSR|Hin6I; M : 100bp; CT : Genotipe CT (470bp, 354bp, 116bp); TT : Genotipe TT (470 bp)

\begin{tabular}{|c|c|}
\hline \multicolumn{2}{|l|}{ DNASequences Transiated Protein Sequences } \\
\hline Species/Abbrv & 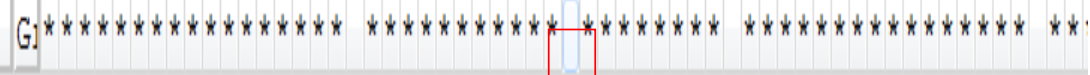 \\
\hline 1. GENBANK & TMTAAGATCATGGAAAGTGATCTTATCECIGCATTAGCAAAGCATCAGCCTTTGCTG: \\
\hline 2. Genotipe CT & TMTAAGATCATGGAAAGCGATCTMATCL-IGCATMAGCAAAGCATCAGCCTMTGCTG: \\
\hline 3. Genotipe MT & TMTAAGATCATGGAAAGCGATCTTATTC-IGCATMAGGAAAGCATCAGCCTMTGCTG: \\
\hline 4. 1811706 25X_GHSR_GHSR R & TMTAAGATCATGGAAAGCGATCTTATTCF-IGCATMAGGAAAGCATCAGCCTTTGTTG: \\
\hline 5. $1811704_{\text {_ AKBKB_GHSR_GHSR R }}$ & TMTAAGATCATGGAAAGCGATCTMATMCE-IGCATTAGCAAAGCATCAgCCTMTGCTG: \\
\hline 6. $1811700_{-} 3$ KBRB_GHSR_GHSR_R & TMTAAGATCATGGAAAGGATCTMATMCHIGCATMAGCAAAGCATCAGCCTMTGCTG: \\
\hline
\end{tabular}

Gambar 3. Delesi basa C pada posisi 134 bp pada ayam kampung berdasarkan referensi dengan nomor akses gen bank AB095994.1 
Tabel 1. Frekuensi genotip, frekuensi alel, heterosigositas dan keseimbangan Hardy Weinberg pada lokus GHSR|Hin6I.

\begin{tabular}{cccccccc}
\hline \multirow{2}{*}{ Gen } & \multicolumn{2}{c}{ Frekuensi Genotipe } & \multicolumn{2}{c}{ Frekuensi Alel } & Ho & He & Keseimbangan HW \\
& TT & CT & T & C & & & \\
\hline GHSR & 0,683 & 0,317 & 0,842 & 0,158 & 0,317 & 0,267 & $* *$ \\
\hline
\end{tabular}

Keterangan : Ho $=$ Heterozigositas Observasi, $\mathrm{He}=$ Heterozigositas harapan, ${ }^{* *}=$ Tidak seimbang dengan Xhitung $>$ Xtabel 0,01 sebesar 6,68 .

Tabel 2. Asosiasi genotipe GHSR|Hin6I dengan sifat bobot karkas dan bobot potongan komersial

\begin{tabular}{lcc}
\hline \multicolumn{1}{c}{ Parameter } & \multicolumn{2}{c}{ Genotipe } \\
& CT $(\mathrm{n}=19)$ & TT $(\mathrm{n}=41)$ \\
\hline Bobot hidup $(\mathrm{g})$ & $603,26 \mathrm{a}$ & $764,51 \mathrm{~b}$ \\
Bobot karkas $(\mathrm{g})$ & $343,84 \mathrm{a}$ & $453,15 \mathrm{~b}$ \\
Dada $(\mathrm{g})$ & $85,737 \mathrm{a}$ & $114,902 \mathrm{~b}$ \\
Paha atas $(\mathrm{g})$ & $64,053 \mathrm{a}$ & $83,415 \mathrm{~b}$ \\
Paha bawah $(\mathrm{g})$ & $59,632 \mathrm{a}$ & $80,073 \mathrm{~b}$ \\
Sayap $(\mathrm{g})$ & $57,842 \mathrm{a}$ & $73,171 \mathrm{~b}$ \\
Punggung $(\mathrm{g})$ & $89,053 \mathrm{a}$ & $114,488 \mathrm{~b}$ \\
\hline
\end{tabular}

Keterangan : Huruf yang berbeda pada baris yang sama menunjukkan ada perbedaan signifikan $(\mathrm{P}<0,05)$

yang besar dan $\leq 0,95$ pada sebuah populasi yang lebih kecil (Alendrof et al. 2013).

Noor (2010) memaparkan bahwa keragaman suatu gen dapat digunakan sebagai tolak ukur dalam menentukan program pemuliaan. Hal tersebut untuk menentukan tindakan seleksi apabila populasi heterogen dan upaya persilangan dilakukan apabila populasi homogen. Nilai heterosigositas sebagai indikator keragaman genetik suatu populasi yang dapat digunakan untuk program seleksi. Suatu SNP dikatakan memiliki keragaman tinggi apabila nilai heterosigositas $>0,50$ (Allendrof et al. 2013). Nilai heterozigositas observasi (Ho) sebesar 0,317, sedangkan untuk nilai heterosigositas harapan $(\mathrm{He})$ sebesar 0,267. Nilai Ho yang lebih rendah dibanding He mengindikasikan adanya inbreeding (Nassiry et al. 2009) Nilai Ho kurang dari 0,50 , hal ini menunjukkan bahwa keragaman genotip populasi ayam kampung pada penelitian ini terhitung rendah.

Keragaman gen GHSR|Hin6I berasosiasi signifikan dengan sifat bobot hidup, bobot karkas, bobot dada, bobot paha atas, bobot paha bawah, bobot sayap dan bobot punggung. Pada gen GHSR genotip TT memiliki bobot yang lebih besar untuk semua parameter yang diamati dibandingkan dengan genotip CT pada taraf $\mathrm{P} \leq 0,05$ (Tabel 2). Data unsex menunjukkan adanya perbedaan signifikan antara genotip CT dan TT, maka dilanjutkan dengan analisis data terpisah antara jantan dan betina. pada ayam jantan genotip TT memiliki nilai yang lebih besar dibanding genotip CT untuk semua parameter. Pada ayam betina, genotip TT lebih dominan untuk semua parameter yang diamati dibanding genotip CT. Genotip TT pada ayam jantan maupun betina memiliki nilai yang lebih besar dibanding genotip CT. Pada penelitian Fang et al. (2010) genotip CT dan TT memiliki nilai pertumbuhan dan bobot karkas yang lebih tinggi dibanding CC. Pada sifat berat otot dada genotip CT memiliki bobot yang lebih besar dibanding bobot pada genotip CC dan TT. Gen GHSR pada lokasi rs16675844 mempunyai efek yang signifikan pada sifat konsumsi pakan dan konversi pakan, sedangkan gen GHSR pada lokasi rs14678932 menunjukkan adanya asosiasi yang signifikan pada sifat berat dada dan konsumsi pakan (Jin et al. 2014).

Gen GHSR pada ayam adalah reseptor ghrelin (GHRL), adapun gen GHSR adalah hormon peptida yang diproduksi oleh proventriculus ayam, yang merangsang pelepasan hormon pertumbuhan $(\mathrm{GH})$ dan asupan makanan (El-Magd et al. 2016). Gen GHSR dapat mempengaruhi pertumbuhan dan bobot karkas ayam karena gen tersebut mempunyai peranan penting dalam proses respon biologis, seperti perkembangan sel, proliferasi, diferensiasi, konsumsi pakan, dan keseimbangan energi (Tschop et al. 2000). GHSR juga banyak dipelajari pada beberapa hewan domestik dan SNPs terkait dengan sifat ekonomis. Mutasi gen GHSR secara signifikan $(\mathrm{P}<0,05)$ berasoiasi dengan beberapa sifat perlemakan seperti kandungan protein kasar, bobot otot paha dan ketebalan lemak subkutan pada ayam dan bebek (Nie et al. 2009). Pada penelitian yang dilakukan oleh El-Magd et al. (2016) ditemukan mutasi lain gen GHSR pada exon 2 (G244A) yang berupa mutasi non-synonymous, adanya perubahan produk asam amino dari lisin menjadi arginin. Keragaman pada gen GHSR juga ditemukan pada penelitian yang dilakukan oleh Kaczor et al. (2016), gen GHSR mempengaruhi bobot potong dan pertambahan bobot harian pada ayam broiler. Hasil penelitian ini menunjukkan gen GHSR memiliki potensi untuk dijadikan penanda awal seleksi bobot karkas pada ayam kampong.

\section{KESIMPULAN}

Pada penilitian ini dapat disimpulkan bahwa gen GHSR|Hin6I pada ayam kampung memiliki 2 genotip yaitu TT dan CT yang berasosiasi dengan bobot karkas dan bobot potongan komersial $(\mathrm{P} \leq 0,05)$. Genotip TT memiliki nilai bobot yang lebih tinggi dibanding genotip CT pada semua sifat yang diamati. Gen GHSR berpotensi untuk dijadikan marka genetik untuk proses seleksi pada sifat bobot karkas dan bobot potongan komersial.

\section{UCAPAN TERIMA KASIH}

Ucapan terima kasih disampaikan kepada Kementrian Riset dan Teknologi melalui program Insentif SINAS 2015 No 12/SEK/INSINAS/PPK/IV/2015 yang telah memberikan dukungan dana pada penelitian ini.

\section{DAFTAR PUSTAKA}

Allendrof FW, Luikart G, Aitken SN. 2013. Conservation and the Genetics of Populations. 2nd Ed. Chicester 
(UK) : Wiley-Blackwell Publishing.

Darwati S, Martojo H. 2001. Pertumbuhan persilangan pelung x kampung pada pemeliharaan intensif. Med Pet. 24:8-11

[DPKH] Direktorat Jendral Peternakan dan Kesehatan Hewan. 2015. Statistik Peternakan dan Kesehatan Hewan 2015. Jakarta (ID) : Kementrian Pertanian.

El-Magd MA, Ayman A, Saleh, Tamer M, Abdel-Hamid, Rasha M, Saleh, Mohammed AA. 2016. Is really endogenous ghrelin a hunger signal in chickens? Association of GHSR SNPs with increase appetite, growth traits, expression and serum level of GHRL, and GH. Gen Comp Endocr. 237 131-139

Fang M, Nie Q, Luo C, Zhang D, Zhang X. 2010. Associations of GHSR gene polymorphisms with chicken growth and carcass traits. Mol Biol Rep. 37:423-428.

Hall TA. 1999. BioEdit: a user-friendly biological sequence alignment editor and analysis program for Windows 95/98/NT. Nucl. Acids. Symp. 41:95-98.

Jin S, Sirui C, Huifeng L, Yue L, Guiyun X, Ning Y. 2014. Associations of polymorphisms in GHRL, GHSR, and IGF1R genes with feed efficiency in chickens. Mol Biol Rep. DOI 10.1007/s11033-014-3265-8

Kaczor U, Poltowicz K, Kuchraski M, Sitarz AM, Nowak J. Wojtysiak D, Zieba DA. 2016. Effect of ghrelin and leptin receptors genes polymorphisms on production results and physicochemical characteristics of $\mathrm{M}$. pectoralis superficialis in broiler chickens. Anim Prod Sci. 57(1) 42-50

Lei M, Luo C, Peng X, Fang M, Nie Q, Zhang D, Yang G, and Zhang X. 2007. Polymorphism of growthcorrelated genes associated with fatness and muscle fiber traits in chickens. Poultry Sci. 86:835-842.

Masayasu K, Kenji K. 2005. Ghrelin : Structure and function. American Psycological Society. Vol. 85. No. 2.

Mattjik AA dan Sumertajaya IM. 2006. Perancangan Percobaan Dengan Aplikasi SAS dan MINITAB. Bogor (ID) : IPB-Pr.
Muryanto, Hardjosworo PS, Herman R, Setijanto $H$. 2002. Evaluasi karkas hasil persilangan antara ayam kampung jantan dengan ayam ras petelur betina. Anim. Prod. 4:2.

Nassiry MR, Javanmard A, Tohidi R. 2009. Application of tatistiscal procedures for analysis of genetic diversity in domestic animal populations. American J Anim Vet Sci. 4(4):136-141.

Nataamijaya AG. 2000. The native chicken of Indonesia. Buletin Plasma Nutfah. Vol. 6, No. 1.

Nataamijaya AG. 2010. Pengembangan potensi ayam lokal untuk menunjang peningkatan kesejahteraan petani. J. Litbang Pertanian 29: 4.

Niarami MD, Masoudi AA, Torshizi RV. 2014. Association of single nucleotide polymorphism of Ghsr and Tgfb2 genes with growth and body composition traits in sire and dam lines of a broiler chicken. Anim. Biotech. $25: 13-22$.

Nie Q, Fang M, Xie L, Peng X, Xu H, Luo C, Zhang C, Zhang X. 2009. Molecular characterization of the ghrelin and ghrelin receptor genes and effects on fat deposition in chicken and duck. JBB. 1-12.

Noor R. 2010. Genetika Ternak. Jakarta (ID): Penebar swadaya

Perdew GH, John PVH, Jeffrey MP. 2006. Regulation of Gene Expression: Moleculer Mechanisms. New Jersey (USA) : Humana Press.Inc

Sambrook J, Maccallum P, Russel D . 2001. Molecular cloning: A laboratory manual, $3 r d$ ed. New York (USA) : Cold Springs Harbour Press.

Tamura K, Peterson D, Peterson N, Stecher G, Nei M, Kumar S. 2011. MEGA5: molecular evolutionary genetics analysis using maximum likelihood, evolutionary distance and maximum parsimony methods. Mol. Biol. Evol. 28(10):2731-2739.

Tschop M, Smiley DL, Heiman ML. 2000. Ghrelin induces adiposity in rodents. Nature 407 : 908-913. 